\title{
Some doubtful locality records of Palmoxylon from Gebel Qatrani Formation, Fayum, Egypt
}

\author{
Samar Nour-El-Deen ${ }^{\mathrm{a}, 1}$,Rifaat Osman ${ }^{\mathrm{b}}$, Wagieh EL- \\ Saadawi ${ }^{\mathrm{a}}$ \\ ${ }^{a}$ Palaeobotany Research Laboratory, Botany Department, Faculty of \\ Science, Ain Shams University, Cairo, Egypt \\ ${ }^{\mathrm{b}}$ Geology Department, Faculty of Science, Benha University, Benha, Egypt \\ Corresponding author. samarnour11@ hotmail.com
}

Samar Nour-El-Deen, Rifaat Osman, Wagieh EL-Saadawi, 2014. Some doubtful locality records ofPalmoxylon from Gebel Qatrani Formation, Fayum, Egypt. Taeckholmia 34: 6776.

\begin{abstract}
In the present note, there are provided details on the doubtful data on the occurrence of some fossil palm species in Gebel Qatrani Formation, Fayum, Egypt.It provides a critical review of the preliminary list of fossil palm wood given by El-Saadawi(2006). It is concluded that only two species, i.e., PalmoxylongeometricumSahniand $P$. pondicherrienseSahni, are considered valid from this locality. While, in the absence of independent confirmation, all other records of Palmoxylonare highly doubtful and preferably disregarded altogether.
\end{abstract}

Key words: Doubtful locality, Palmoxylon, Gebel Qatrani Formation, Oligocene, Egypt.

In general, published data on palm fossil woods from Egypt are limited and may even be scarce from Gebel Qatrani Formation. A general report on paleoflora of Gebel Qatrani has been published by El-Saadawi (2006), whodocumented, as much as possible, all of the data existing on plant fossil remains of Gebel Qatrani Formation. In the presentpaper, we provide a critical review of all Palmoxylon taxa recorded earlier from Gebel Qatrani Formation and listed in El-Saadawi (2006).

Received 19 Sep. 2014, Accepted 1 Nov. 2014 
We provide details of the recorded data on the occurrence ofPalmoxylon species. These details are based on data comprised from the available literature and from data about collections kept in the Botany Department, Faculty of Science,Ain Shams University, Cairo, Egypt. The literature datago back to 1880; they are not easily accessible to paleobotanists and the majority of them was published before 1940 and written in Dutch.

We have included an enumeration of all the localities from Egypt whence these Palmoxylon species have been reported. The exact spelling and description of the locality is given from the literature; whenin German, it is cited first, followed by the English translation. The species are arranged chronologically in the order of their appearance in Egyptian fossil records.Synonyms to all species from Egyptian localities are taken into account and taxonomic notes on some records are given when necessary.

According to El-Saadawi (2006), five species of Palmoxylonhad been reported from Gebel Qatrani, viz., $P$. aschersoniSchenk, $P$. geometricumSahni, $P$. lacunosum(Unger) Felix, $P$. libycum(Stenzel) Kraüsel, and $P$. pondicherrienseSahni. It seems convenient to review these few records in the following context at some length.

1. PalmoxylonaschersoniSchenk, 1883. FossileHoelzer, S. 6, Taf. II, Fig. 4.

Synonyms:

- $\quad$ PalmacitesaschersoniSchenk, 1880. Botan. Zeitung S. 658.

- Palmoxylonaschersonia)verumStenzel, 1904. Foss. Palm. S. 235, Taf. XX, Fig. 232.

- Palmoxylonaschersonib)schweinfurthiStenzel,. 1904. Foss. Palm. S. 236, Taf. XX, Fig. 233, 234.

- Palmoxylonschweinfurthi Schenk(listed in synonyms of $P$. aschersoni by Stenzel (1904) based on annotations on thin sections).

Localities.- Schenk (1880), under Palmacitesaschersoni: "kommtimNilthalebei Cairo vor" occurs in the Nile Valley in Cairo. Schenk (1883): "In der Nähe der grossenPyramidebei Cairo (Zittel!)" Near the Great Pyramid in Cairo.(Zittel!). - Specimens also examined by Stenzel(1904), under Palmoxylonaschersonia)verum: "ImNiltaleunweit der großenPyramide von GizehbeiKairo in Ägypten von Zittelgefunden" In the Nile valley not far from the great pyramid of Giza near Cairo in Egypt, found by Zittel (cited in Schenk in Bot. Zeitung 1880, S. 658); "OaseFayum 
SSW. der großenPyramidebeiKairo" Fayum Oasis, SSW of the great pyramid near Cairo (cited in Schenk in Zittel II, Handbuch der Palaeontologie, Abt. 2, 1890, S. 886 as "Aegypten: OaseFayum, SWS der grossenPyramide, nördlichsterTheil der östlichenWüstebei Cairo" Egypt: Fayum Oasis, SWS of the great pyramid, the northernmost part of the eastern desert near Cairo); "Kairo-Suez, nördlichsterTeil der östlichenWüste, von Schweinfurthgefunden (nacheinerAngabe auf einemDünnschliffaus der Sammlung von Schenk, jetzt in der von Prof. Felix)" Cairo-Suez, the northernmost part of the Eastern Desert, found by Schweinfurth (according to a statement on a thin section from collection of Schenk, now in the collection of Prof. Felix).--Stenzel (1904), under Palmoxylonaschersonib) schweinfurthi: "ZwischenKairo und Suez, wohl von Schweinfurth" Between Cairo and Suez, probably by Schweinfurth; "beiBirLebuk in Ägypten von Ehrenberg gefunden" at Bir (= well)Lebuk ${ }^{1}$ in Egypt, found by Ehrenberg. —Kräusel\&Stromer (1924): "Kairo 578. Norden des Fajum.?Unteroligozän" Cairo 578 (corrected inKräusel (1939) to be Cairo 5728) North of Fayum, ?lower Oligocene; "Nähe der großen Pyramid von Gizeh. Oberoligozän" Near the great Pyramid of Giza. UpperOligocene (Original material of Schenk).-Kräusel (1939): One sample from Qatrani-Stufe? (listed in the Table on page 118).

Palmoxylonaschersoni has been recorded only once from Gebel Qatrani by Kräusel (1939).The first record of this species dates back to 1880, when Joseph August Schenk gave a short account on the data collected by Gerhard Rohlf's expedition to the Libyan Desert (Western Desert of Egypt) and Cairo petrified forest. He included two fossil palm woods and two dicot woods. The fossil palm species were originally recognized by Schenk, who referred them to the genusPalmacites, viz., Palmacitesaschersoni Schenk and $P$. zittelii Schenk (nomennodum); see Schenk (1880).

Three years later, Schenk (1883) described these two species in detail with line drawings (see, p. 6 and 7, Taf. II, Fig. 4), but transferred them to the genus Palmoxylon, i.e., Palmoxylonaschersoniand $P$. zitteli. The type locality of $P$. aschersoni was given as: Near the Great Pyramid in Cairo (Zittel!).

Later on, in his exhaustive monograph on fossil palms, Stenzel (1904) included the Egyptian material identified by Shenck as 
Palmoxylonaschersoni, but as a form named P. aschersoni Schenk verumStenzel. He also included another form of $P$. aschersoni named schweinfurthi; based on examination of different Egyptian materials. Nevertheless, Stenzel suspected, but could not prove, that both forms represent the outer and inner parts of the same stem.

Then, Kräusel subsumed Stenzel's forms (verum and shweinfurthi) under $P$. aschersoni(Kräusel and Stromer, 1924). He examined material of more than $10 \mathrm{~cm}$ in diameter and proved that a transition in structure and composition is found between outer and inner zones of the same stem. The outer zone resembles the verum form and the inner zone resembles the shweinfurthi form. Furthermore, comparing the illustrations provided by Schenk (1883) and Stenzel (1904), Kräusel found that it is untenable to distinguish between Schenk's $P$. aschersoni and the two forms recognized by Stenzel. Consequently, he concluded that both forms of Stenzel must be reduced to synonyms of $P$. aschersoni.

In 1939, Kräusel listed $P$. aschersoni among other species that represent the Egyptian fossil flora (Kräusel 1939, the Table on p. 17). He adopted Stromer's division of fossiliferous strata in Egypt, who grouped Qatrani Formation and Gebel Ahmer Formation into one category, namely, level 9 under the Tertiary, lower Oligocene. But in the same paper, Kräusel reported on the presence of $P$. aschersoni from both locations,i.e., Gebel Qatrani and Gebel-Ahmer, one sample each (see, the Table on p. 118); without reference specimen, description, figures, or any further data.Obviously, Kräusel's reports on P. aschersoni in the 1939's paper refer to the material included in the 1924's paper. As he indicated (in the Table on p. 17)thatthetaxon namemarked withasterisk (*) in the list refers to the 1924's paper.

A common note that can be gleaned from this overview is that all previous reports of $P$. aschersoni refer to places outside the Fayum except for the single questionable one reported by Kräusel (1939).Further evidence of suspicionaboutKräusel's report from Gebel Qatrani comes from the notation given by Stromer, who dealt with this locality on pp. 11-14 (Kräusel\&Stromer, 1924), he mentioned that he did not see any palm wood among plant fossil remains from Qatrani Formation "Was die Pflanzenformen der Qatrani-Stufeanlangt, so habeichdortkeine Palmenhölzergesehen" (Kräusel\&Stromer, 1924: p. 13).Taking all together, we regard the Gebel Qatrani locality doubtful until more collections of $P$. aschersoniconfirm its presence there. 


\section{Palmoxylonlibycum (Stenzel) Kräusel 1924 Synonyms:}

- PalmoxyloncottaeUngerlibycumStenzel, 1904. Foss. Palm. S. 221, Taf. XIII, Fig. 136, 137.

- PalmoxylonaschersoniSchenk,partly, on thin sections in the collection of Prof. Felix in Leipzig; 1904. Foss. Palm. S. 221.

Localities.- Stenzel (1904), under PalmoxyloncottaeUngerlibycum: "Ägypten: $15 \mathrm{~km}$ WSW. von der großenPyramide" Egypt:15 km WSW of the Great Pyramid; "Nördlich von Birked el Querun. Schweinfurth" North of Birket (lake) Qarun.Schweinfurth.-Kräusel\&Stromer (1924), as $P$. libycum: Stenzel-mentioned localities (as above); besides other specimens from different localities from lower Miocene or without locality data. Kräusel(1939), as P. libycum: One sample from Qatrani-Stufe (listed in the Table on page 118).

Stenzel(1904) refuted the identification of the material from the first locality (i.e., $15 \mathrm{~km}$ !!of the Great Pyramid) as $P$. aschersonibecause the sclerenchyma part is not lunate and the vascular part of the firbrovascular bundles contains more than one xylem vessel, which are amongthe important distinguishing characters for $P$. aschersoni. He assumed a relationship to $P$. cottaeUngerverumStenzel, but due to the absence of pure fibrous bundles, he treated it as a separate form named P.cottaeUngerlibycumStenzel referring to the Libyan Desert (Western Desert of Egypt) from whereall materials had been collected.

Later on, Kräusel (in Kräusel\&Stromer, 1924) argued that $P$. cottaeUngerlibycumStenzel should not be placed under $P$. cottae due to the absence of fibrous bundles in the ground tissue of the former, which is considered an important taxonomic character in species differentiation. $\mathrm{He}$ treated the material as a distinct species designated as $P$. libycum (Kräusel\&Stromer, 1924).

As for the specimen from the second locality (i.e., North of lake Qarun), Stenzel(1904) pointed out that it differs from the first material only in minor characters and concurs with it in some aspects of fossilization; thus one would think that they were found at the same location. He alsoindicated that lake Qarun is situated about 8 miles $(\sim 12.87 \mathrm{~km})$ from the great Pyramid and since Schweinfurth describes the location as "north of lake Qarun", the specimen may probably have been found very close to the first locality.It is hard to tell what area is considered by Schweinfurth as being "north of" 
Lake Qarun. In addition, this reference is the only source for this species found by now from Gebel Qatrani. According to us, this locality is - or could be considered as-doubtful and should be checked by further collection.

\section{Palmoxylonlacunosum (Unger) Felix. 1882. Stud. Foss. Hölz. S. 78. Synonyms: \\ - $\quad$ Palmoxylonlacunosuma)verumStenzel 1904. Foss. Palm. S. 187, Taf. VI, Fig. 64-66. \\ - FasciculiteslacunosusUnger 1845. In Martius, Gen. et. Spec. Palm. S. 58, \$ 16, tab. Geol. I, Fig. 1, II, Fig. 8, III, Fig. 1. \\ - Fasciculitesanomalus Unger 1845. In Martius, Gen. et. Spec. Palm. S. 58, \$ 16, tab. Geol. I, Fig. 1, II, Fig. 8, III, Fig. 1.}

Localities.— Kräusel\&Stromer (1924), four specimens from "Fajum. Unteroligocän" Fayum, lower Oligocene; "FaustgroßeStücke.Etwa 20km OSO von Der Abu Makar" fist-sized pieces.Approximately 20km ESE of Der (monastery) Abu Makar. — Kräusel (1939), four samples from Qatrani-Stufe(listed in the Table on page 118).

Palmoxylonlacunosum has been reported once from Egypt in Kräusel\&Stromer (1924) based on materials collected from Fayum (lower Oligocene) and from about $20 \mathrm{~km}$ ESE of Der Abu Makar (the oldest monastery in WadiNatrun, lower Miocene).

The Oligocene locality in Fayum considered the origin of $P$. lacunosum(Kräusel\&Stromer, 1924).Bearing in mindStromer's notation on the absence of fossil palms from Gebel Qatrani (see comments under $P$. aschersoni) and the lack of detailed collecting data, one could not know for certain whether the intended material has been found in Gebel Qatrani as Kräusel gives no locality within Fayum (cf., Kräusel\&Stromer, 1924).

Moreover, Kräusel (1939) provided a comparative table (cf., the Table on page 118) includes all fossil wood taxa recorded from Gebel Qatrani and Gebel Ahmer. In this table, he pointed out that four samples of $P$. lacunosumare found in Gebel Qatrani and no records at all from Gebel Ahmer! Comparing between the data provided by Kräusel in these two publications, one would conclude that the four samples referred to Fayum in the 1924's paper are the same four samples referred to Gebel Qatrani in the 1939's paper. 
These apparently inconsistent locality data cast doubt on the occurrence of this species in Gebel Qatrani. It seems plausible to think that some of these questionable records result from a failure to distinguish between the following regions: Cairo Petrified Forest, Gebel Qatrani Formation, and Gebel Ahmer Formation, which are all located north of Fayum (see Fig. 1). Clearly there is a need for further consideration of P. lacunosum presence in Gebel Qatrani Formation.

\section{PalmoxylongeometricumSahni1964. Revision of Indian Fossil Palms. Part II. Monocotyledons. P. 53, 54. Pl. 5, Fig. 36-39.}

5. PalmoxylonpondicherrienseSahni 1931. Proc. Acad. Sci. U.P. 1: 140144. p. 143.

Localities (for taxa 4 \& 5). - El-Saadawi et al (2004): Gebel Qatrani, early Oligocene (or late Eocene)

The most recent records of fossil palms from Gebel Qatrani Formation are $P$.geometricumand $P$. pondicherriense, which have been reported by ElSaadawiet al (2004) without indication to the exact localities, strata, or any further details about collection process.

Summing altogether (see Table 1), it is concluded that the only specimens that could be referred without doubt to Qatrani Formation are the recent two species recorded by El-Saadawi et al (2004). In almost all previous publications records are not reported with unequivocal collecting data, and so are not definitely known to occur at Gebel Qatrani Formation.

\section{References}

Dixon, W., 1873.A petrified forest in the Libyan Desert.Nature, March 13, 1873 , p. 363-364.

El-Saadawi, W., Youssef, S.G.M., Kamal-El-Din, M.M., 2004. Fossil palm woods of Egypt: II. Seven Tertiary Palmoxylon species new to the country. Rev. Palaeobot. Palynol. 129, 199-211.

El-Saadawi, W., 2006.On the fossil flora of Jebel Qatrani area, Fayum, Egypt.Taeckholmia 26, 131-140.

Gingerich, P. D. (1992). Marine mammals (Cetacea and Sirenia) from the Eocene of Gebel Mokattam and Fayum, Egypt: stratigraphy, age, and paleoenvironments. University of Michigan Papers on Paleontology, 30: 1-84. 
Kräusel, R., Stromer, E., 1924. Ergebnisse der Forschungsreisen Prof. E. Stromers in den Wüsten Ägyptens, IV. Die fossilenFlorenÄgyptens 1-3. A-C. Abh.Bayer.Akad.Wiss. Math.-Nat. Abt. 30 (2), 1-48.

Kräusel, R., 1939. Ergebnisse der Forschungsreisen Prof. E. Stromers in den Wüsten

Ägyptens, IV. Die fossilenFloren ̈̈gyptens 3. Die fossilen Pflanzen Ägyptens, E-1:

Abh.Bayer.Akad.Wiss.,München N. F., 47, pp. 1-140.

Sahni, B., 1931, Material for a monograph of Indian petrified palms. Proceedings of the Academy of Sciences, 1, 140-144.

Sahni, B., 1964, Revision of Indian Fossil Plants III, Monocotyledons. Monograph No. 1: Lucknow, India, BirbalSahni Institute of Palaeobotany, 1-89.

Said, R. 1990.Cenozoic. In: R. Said (editor), The Geology of Egypt. Rotterdam, Netherlands, A. A. Balkema Publishers, p. 451-486.

Schenk, A., 1880. UeberfossileHölzeraus der Libyschen Wüste. (Botan. Zeitung. XXXVIII. Nr. 39. p. 657-661). In Botanisches Centralblatt.Referirendes Organ für das Gesammtgebiet der Botanik des In- und Auslandes. Herausgegebenunter Mitwirkungzahlreicher Gelehrten von Dr. Oscar Uhlworm, Custos der Universitäts-Bibliothek in Leipzig.;ErsterJahrgang. 1880. II Semester. p. 1571, 1752.Verlag von Theodor Fischer, Kassel: Germany.

Schenk, A., 1883. FossileHölzer. Palaeontographica 30 (2), 1-19.

Stenzel, K. G., 1904.FossilePalmenhölzer. Palaeontology und Geologie Osterreich-Ungarns und des Orients: Mittelungen der Gesellschaft der Geologie und Paläontologischen, InstitutUniversitat Wien, v. 16, p. 107-288.

Schimper, W. Ph., Schenk, A., 1890.Handbuch der Palaeontologie (ed. K. A. Zittel) II.Abtheilung: Palaeophytologie.Muenchen und Leipzig, Druck und Verlag von R. Oldenbourg. 
Table 1. List of Palmoxylon taxa earlier reported from Gebel Qatrani.

\begin{tabular}{|l|l|}
\hline Taxon & Reference \\
\hline Palmacites aschersoni Schenk? & Schenk 1880 \\
\hline \multirow{3}{*}{ Palmoxylon aschersoni Schenk* } & Schenk 1883 \\
\cline { 2 - 2 } & Kräusel \& Stromer 1924 \\
\cline { 2 - 2 } & Kräusel 1939 \\
\hline Palmoxylon aschersoni Schenk verum Stenzel $* ?$ & Stenzel 1904 \\
\hline Palmoxylon aschersoni Schenk schweinfurthi Stenzel*? & Stenzel 1904 \\
\hline Palmoxylon cottae Unger libycum Stenzel? & Stenzel 1904 \\
\hline Palmoxylon libycum (Stenzel) Kräusel* & Kräusel \& Stromer 1924 \\
\hline Palmoxylon lacunosum (Unger) Felix* & Kräusel \& Stromer 1924 \\
\hline Palmoxylon geometricum Sahni & El-Saadawi et al. 2004 \\
\hline Palmoxylon pondicherriense Sahni & El-Saadawi et al. 2004 \\
\hline
\end{tabular}

* Indicates taxa excluded from Qatrani fossil flora.

? Indicates names reduced to synonyms. 


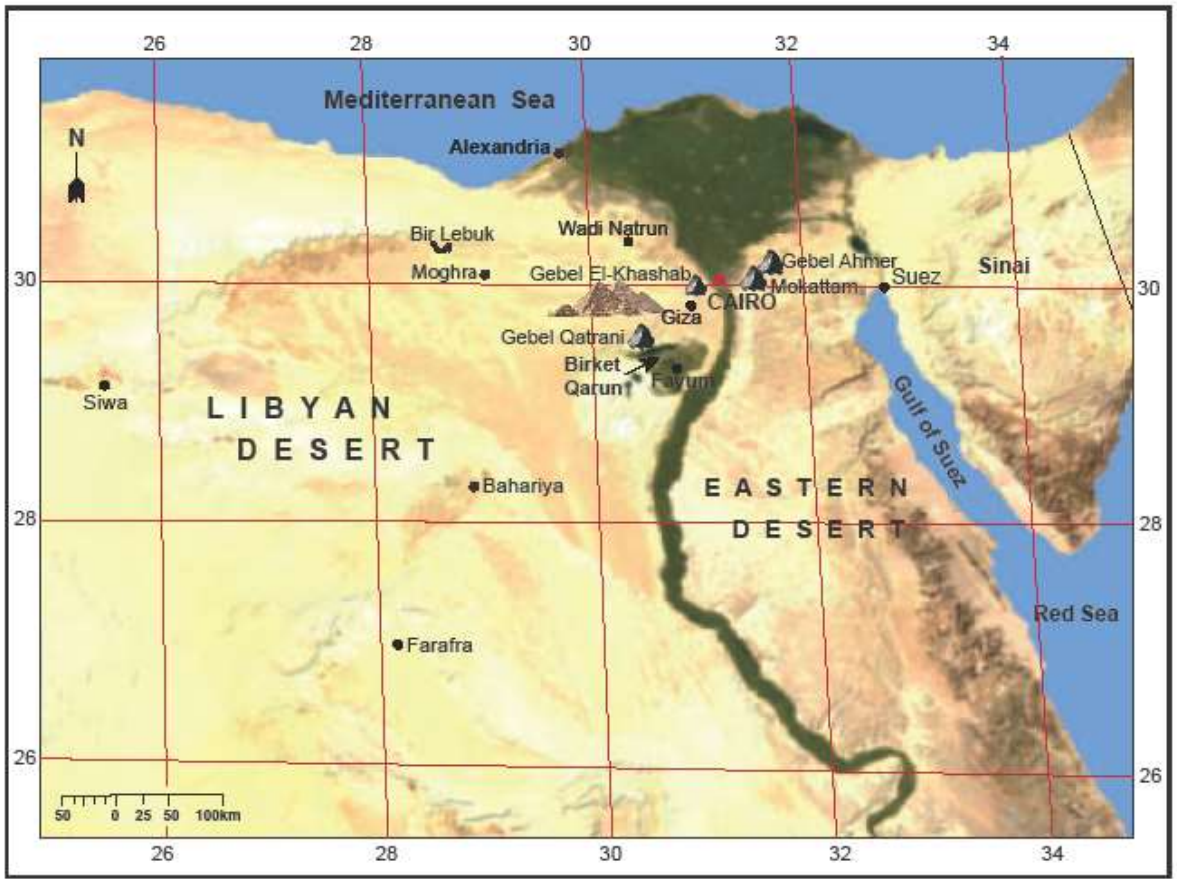

Figure 1. Map showing all localities cited in the literature for the previously recorded Palmoxyla attributed to Gebel Qatrani Formation. A list of other names or designations for the locality, some of them now obsolete, are given. Gebel Mokattam is located east of Cairo (in the Eastern Desert) and bounded on the north by Gebel Ahmer. The lower part of Mokattam Formation yielded Cairo Petrified Forest (the most famous Petrified Forest in the Country). It is also known as Mokattam Petrified Forest, Maadi Petrified Forest (a protectorate), Qattamiya Petrified Forest, and Gebel El-Khashab east of Cairo (Said, 1990, Gingerich 1992). It should be noticed, however, that Gebel El-Khashab east of Cairo is totally different from Gebel El-Khashab in the Western Desert, which is located $602 \mathrm{ft}(183.49 \mathrm{~m})$ above the north-east socket of the Great Pyramid (Dixon, 1873). This was enumerated as one of the Pyramids of Egypt and was called "DrLeider's Pyramid", but then renamed Kôm el Khashab "the hill of wood" by Waynman Dixon and Dr Grant of Cairo (Dixon, 1873). It worth mentioning that silicified tree trunks concentrated in certain areas are commonly referred to as Petrified Forest (or Gebel "mount" El-Khashab "wood" in Arabic). Gebel Ahmeris located northwest of Gebel Mokattam, and it is now renamed Gebel Akhdar under Nasr City (Said, 1990, Gingerich 1992). 